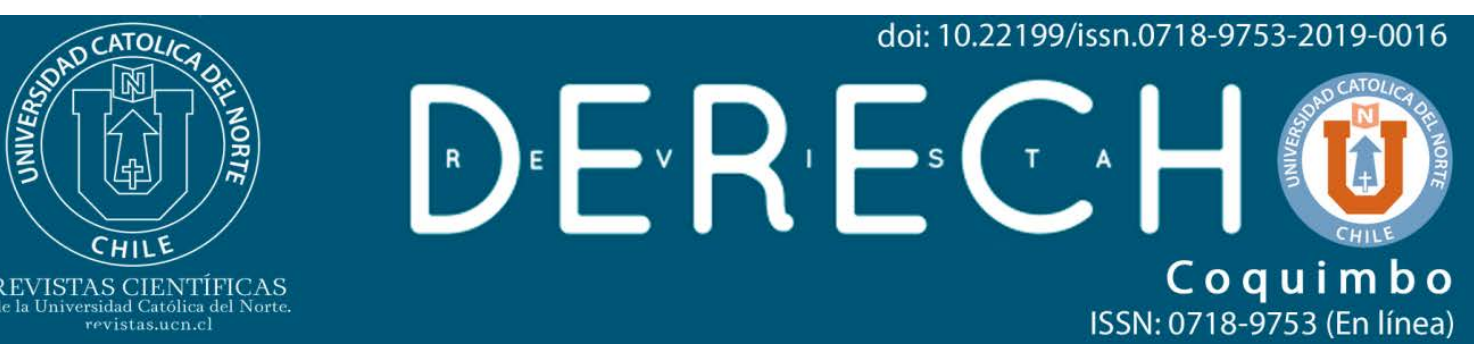

\title{
Algunos aspectos de la cláusula penal en el derecho chileno
}

\section{Some aspects of the liquidated damages clause in Chilean law}

\author{
Arturo Prado Puga* (iD) https://orcid.org/0000-0001-8089-4136 \\ *Universidad de Chile. Profesor. Ministro de la Corte Suprema. Doctor en Derecho, U. de Navarra. \\ @ arturopradopuga@gmail.com \\ (cc) BY
}

\section{Resumen:}

Se desarrolla el estado actual de la cláusula penal en Chile. Se analizan las fuentes que influyeron en la consagración de esta institución en el Código Civil chileno, derecho español y derecho francés durante la época codificadora del siglo $X I X$. Se caracteriza a la cláusula penal como una convención accesoria, condicional y avaluación anticipada y convencional de perjuicios. Se considera clasificable en compensatoria y moratoria, existiendo una tercera opción si las partes la acuerdan con una finalidad punitiva expresamente. Se expone sobre la posibilidad de acumulación del cumplimiento de la obligación y la pena como indemnización, así como también, la posibilidad de acumular una pena moratoria y una pena compensatoria. Se plantea y analiza los requisitos exigidos para la ejecución de una cláusula penal: siendo una avaluación convencional y anticipada de los perjuicios se deben cumplir con los elementos constitutivos de responsabilidad contractual. Por lo tanto, deberá existir un incumplimiento contractual, imputabilidad inexcusable, constitución en mora, daño y causalidad. Se recalca que para la constitución en mora, en el cumplimiento de una cláusula penal, es necesaria la interpelación judicial, es decir, la notificación válida de la demanda. Por último se desarrollan las reglas sobre la carga probatoria y necesidad de acreditar cada uno de los elementos de la responsabilidad contractual en esta institución.

Palabras Clave: Cúmulo de responsabilidades; Enriquecimiento sin causa; Mora; Indemnización de perjuicios.

\begin{abstract}
:
The current status of the liquidated damages clause in Chile is developed. The sources that influenced the consecration of this institution in the Chilean Civil code, Spanish law and French law during the codifying period of the 19th century are also analyzed. The liquidated damages clause is characterized as an accessory convention, conditional and predetermined and conventional estimation of the damages by the parties. It is a clause that is considered classifiable in compensatory and moratorium, with a possible third option of classification, in case the parties agree for it to be a penalty clause. The paper also exposes the possibility of accumulation of compliance with the obligation and the penalty as compensation, as well as the possibility of accumulating a moratorium penalty and a compensatory penalty. The requirements demanded for the execution of a liquidated damages clause are presented and analyzed: being a conventional and predetermined estimation of the damages, the constituent elements of contractual responsibility must be fulfilled. Therefore, there must be a breach of contract, inexcusable imputability, constitution in default, damage and causation. It is emphasized that for the constitution in default, in compliance with a liquidated damages clause, judicial interpellation is necessary, that is, the valid notification of the claim. Finally, the rules on the burden of proof and the need to prove each of the elements of contractual responsibility in this institution are developed.

Keywords: Cumulation of responsibilities; Enrichment without cause; Arrears; Compensation for damages.
\end{abstract}




\section{Antecedentes históricos de la institución y precedentes del Códi- go Civil chileno}

Con importantes diferencias es posible afirmar que el Código Civil francés de 1803, fuertemente influenciado por el derecho romano y canonista, es la fuente histórica de las codificaciones del derecho que marcan la tradición civil en esta materia, cuyo es el caso para Chile. Sin embargo, como se analiza más adelante, nuestro legislador, recogió importantes influencias del proyecto de Código Civil español de García Goyena, modificando lo dispuesto por el legislador francés.

\subsection{En el Código Civil francés}

El legislador francés trata de las cláusulas penales dentro del derecho de los contratos. El Código Civil consagra expresamente las cláusulas penales en la Section VI Des obligations avec clauses pénales', Chapitre IV Des diverses espèces d'obligations², Titre III Des contrats ou des obligations conventionnelles en général, ${ }^{3}$ Livre troisième - des différentes manières dont on acquiert la propriétét $e^{4}$ Esta institución contractual se encuentra regulada bajo el contexto del derecho de las obligaciones, particularmente en el de contratos, su fuente principal, desde los artículos 1226 al 1233.

La cláusula penal en el derecho francés está establecida igualmente como garantía o caución para asegurar el cumplimiento de una obligación principal. ${ }^{5}$ Es decir, al igual que para el caso chileno, la cláusula penal sería un contrato que accede a otro principal, con el objeto de asegurar el cumplimiento de este último, por la vía de hacer exigible una pena en caso que no se verifique el cumplimiento de la obligación principal por parte de su deudor, igualmente contemplando la posibilidad de establecerla para indemnizar los perjuicios moratorios.

Al igual que en el derecho chileno, dedica en su tratamiento atención a la obligación de poner en mora al deudor y el cúmulo de penas, esto es, determinar si puede sumarse a la exigencia de la pena estipulada, alguna otra prestación adicional por parte del deudor incumplidor. Para estos efectos, el Código Civil francés destina los artículos 1228 y 1229. El primero, establece que es el derecho del acreedor exigir al deudor

\footnotetext{
1 "Sección VI, de las obligaciones con cláusulas penales" (NR: Todas las traducciones fueron realizadas por el autor).

2 "Capítulo IV, de las diversas especies de obligaciones".

3 "Título III, del contratos o de las obligaciones convencionales en general".

4 "Libro tercero, De las diferentes maneras en que se adquiere la propiedad".

${ }^{5}$ Artículo 1226 Código Civil francés: "La cláusula penal es aquella por la cual una persona, para asegurar el cumplimiento de una convención, se compromete a algo en caso de no cumplimiento".
} 
moroso la pena estipulada o bien perseguir el cumplimiento de la obligación principal. ${ }^{6}$

De lo anterior, se desprenden dos conclusiones, la primera es que requiere de la constitución en mora del deudor, y la segunda, al igual que en nuestro derecho, afirma positivamente que el acreedor tendrá derecho para elegir por un lado la aplicación de las normas generales sobre responsabilidad contractual respecto de la obligación principal que el deudor se encuentra en mora de cumplir, o bien, por otro lado, optar por exigir la pena accesoria. Es decir, el acreedor tiene positivamente el derecho de exigir una u otra cosa, mas no ambas.

En un sentido negativo, el artículo $1229^{7}$ del mismo código, prohíbe que pueda pedirse directamente la responsabilidad contractual respecto de la obligación principal y al mismo tiempo la pena dispuesta en la cláusula penal. Lo anterior, se explica por cuanto la cláusula penal corresponde a la indemnización de perjuicios a que tiene derecho el acreedor de la obligación principal en caso de incumplimiento por parte de su deudor. Naturalmente, esto responde al principio de prohibición de enriquecimiento injusto que informa ambos códigos civiles, que se daría con ocasión de un doble pago por una sola y misma causa. "El código francés dio la pauta en este punto al disponer que el acreedor puede optar entre exigir la ejecución de la obligación principal o la pena, pero sin que pueda acumular ambas, salvo que se trate de pena moratoria" (Arts. 1228 y 1229 inc. $2^{\circ}$ ) (Corral Talciani, 2012, p. 148) e indica que la pena viene en sustituir la indemnización de perjuicios por el incumplimiento contractual, según lo dispuesto en el artículo 1229 inc. $1^{\circ}$.

El Código Civil francés expresa una excepción aparente: en caso de haberse dispuesto por el solo retardo, podrá exigirse el cumplimiento de la obligación principal y la pena moratoria. Como ya vimos, esta sería una excepción sólo aparente, ya que el daño por el cumplimiento tardío y el daño por el incumplimiento son del todo diferentes y así se encuentran reconocidos dentro de las normas generales de responsabilidad contractual.

\subsubsection{Doctrina francesa afín a esta interpretación:}

En este mismo sentido y como explican los autores Mazeaud, Mazeaud y Tunc (1977, 142 y ss.), el acreedor de una obligación garantizada con cláusula penal, no está nunca constreñido a alegar la pena. Esta última, se traduce en una reparación que toma el lugar de la indemnización de perjuicios, por una suma que las partes preestablecen por la vía contractual.

\footnotetext{
${ }^{6}$ Artículo 1228 Código Civil francés: "El acreedor, en lugar de demandar la pena estipulada contra el deudor que está en mora, puede perseguir el cumplimiento de la obligación principal".

${ }^{7}$ Artículo 1229 Código Civil francés: "La cláusula penal es la compensación de los daños y perjuicios que el acreedor sufre por el incumplimiento de la obligación principal. No puede demandarse al mismo tiempo lo principal y la pena, a menos que haya sido estipulada para el simple retardo".
}

Rev. derecho (Coquimbo, En línea) 2019, 26: e3893 
Ahora bien, esto pone al acreedor en la situación de tener que elegir entre una y otra. Por tanto y como bien afirman los profesores, no puede acumular la condena en especie con la reparación equivalente. Es decir, no puede reclamar el cumplimiento forzado (cumplimiento de la obligación bajo astreinte) y el pago de la pena.

Respecto a la pena moratoria, los profesores agregan que esta parte del texto sobre las cláusulas penales, se condice con las reglas generales, esto es, que los daños y perjuicios moratorios no excluyen los daños y perjuicios compensatorios.

Igualmente, en caso de demandar la resolución del contrato, se estaría pidiendo un equivalente pecuniario, por lo que tampoco bajo esta hipótesis puede acumularse la pena. Suman a lo anterior, que la extinción de la obligación principal por vía de resolución, arrastra consigo la de la cláusula penal, en razón de su accesoriedad. El mismo resultado se produciría en caso de nulidad de la obligación principal.

En concordancia con la doctrina recién citada, Larroumet (1999, pp. 124 y ss.) confirma que la pena convencional representa la avaluación a suma alzada de los perjuicios que sufra el acreedor de la obligación principal, en caso de incumplimiento de parte de su deudor. Explica que, puesto que se encuentra inserta dentro del mecanismo de la responsabilidad contractual, la cláusula penal tiene un doble objeto: la reparación del daño sufrido por el acreedor, más una función coercitiva para los mismos efectos.

Por encontrarse en dicho contexto y por perseguir la reparación de un daño, requiere necesariamente la constitución en mora del deudor incumplidor, o bien un retardo en el cumplimiento si para dichos efectos fue estipulado.

Otra consecuencia de ser una avaluación convencional de los daños y perjuicios, es que el beneficio de la cláusula penal no se puede acumular con la ejecución forzosa en especie. Es decir, si la cláusula penal representa una ejecución forzosa por equivalencia, no puede sumarse, una vez constituido en mora y por regla general ${ }^{8}$, a una ejecución forzosa en especie, ya que representaría un doble pago a una misma obligación.

Sin embargo, Larroumet (1999) hace una distinción respecto de las obligaciones de dinero, cuando el contrato principal tiene tal objeto y la cláusula penal se establece para prevenir el caso de resolución del contrato.

\footnotetext{
${ }^{8}$ Art. 1537. del Código Civil : "Antes de constituirse el deudor en mora, no puede el acreedor demandar a su arbitrio la obligación principal o la pena, sino sólo la obligación principal; ni constituido el deudor en mora, puede el acreedor pedir a un tiempo el cumplimiento de la obligación principal y la pena, sino cualquiera de las dos cosas a su arbitrio; a menos que aparezca haberse estipulado la pena por el simple retardo, o a menos que se haya estipulado que por el pago de la pena no se entiende extinguida la obligación principal".
} 
A diferencia de la regla general que defienden los hermanos Mazeaud y André Tunc, Larroumet (1999, pp. 110 y ss.) afirma que cabe exigir la cláusula penal que representa una multa para el caso en que una obligación de dinero -principal- se vea extinguida por la resolución.

\subsubsection{Conclusión de la doctrina francesa}

El Código Civil francés, fuente de nuestro código, reconoce expresamente la existencia y validez de las cláusulas penales, como contratos que acceden a otro principal, para establecer una pena a favor del acreedor en caso de incumplimiento del deudor.

Ya que las normas sobre responsabilidad contractual operan tanto sobre la obligación principal incumplida como sobre el contrato de cláusula penal, por la misma causa de incumplimiento, cabe revisar si es posible el cúmulo de penas previstas por la ley y por las partes.

Los autores citados están de acuerdo en que la pena convencional y anticipada, juega exactamente el mismo rol que la indemnización de perjuicios que se podría pedir por el incumplimiento de la obligación principal, por lo que no podrían acumularse una y otra.

Por regla general, tampoco cabría solicitar la pena en caso de resolución del contrato, ya que la propia resolución sería una reparación no pecuniaria, además que arrastraría la resolución del contrato accesorio.

Igual resultado daría el caso de declaración de nulidad de la obligación principal.

Sin perjuicio de lo señalado anteriormente, según el segundo autor, no estaría prohibido estipular la cláusula penal como multa, exigible con ocasión de la resolución de un contrato que verse sobre una obligación de dinero pactándose, precisamente, para este evento.

Con todo, los autores concuerdan que la regla general es la prohibición del cúmulo, el caso de la pena moratoria sería una excepción sólo aparente y el caso de la resolución de la obligación de dinero responde a un distingo que debe pactarse expresamente para dicho evento, lo que se asemeja a los requisitos de la cláusula penal punitiva.

\subsection{Influencia del derecho español. Proyecto de Código Civil 1851, el proyecto de García Goyena}

Don Florencio García Goyena (1852), fue conocido como uno de los redactores del Código Civil español. De ahí, su conocida obra Concordancias, Motivos y Comentarios del Código Civil español, cuya importancia para nuestros efectos, es la de 
Algunos aspectos de la cláusula penal en el derecho chileno.

haberse basado, entre otros, en el Código Civil francés y de haber influido en don Andrés Bello para la redacción del Código Civil chileno.

El Proyecto de Código Civil español de 1851, en comento, regulaba las cláusulas penales, en su Libro III "De los modos de adquirir la propiedad", Título V "De los contratos y obligaciones en general", Capítulo IV "De las diversas especies de obligaciones", Sección VIII "De las obligaciones con cláusula penal" (García Goyena, 1852, pp. 351 y 352).

Dicha sección está comprendida entre los artículos $1079^{9}$ y 1085 , inclusive.

Indica este autor, que la cláusula penal tiene por objeto asegurar la ejecución del contrato u obligación principal, con carácter de accesorio. En consecuencia la nulidad de la obligación principal, lleva consigo la nulidad de la obligación penal. Además indica que puede ser nula por la imposibilidad en su ejecución.

Sobre el cúmulo de penas, el Código Civil español de 1851, consagra la regla general en su artículo 1081. Dicho artículo establece que:

"el acreedor puede reclamar a su elección el cumplimiento de la obligación o el de la pena estipulada contra el deudor moroso. Únicamente podrá reclamar las dos cosas si así se hubiere pactado; en cuyo caso podrán los tribunales moderar la pena si fuere excesiva.

La cláusula penal es la compensación de los daños é intereses causados por la falta de cumplimiento de la obligación; pero en las obligaciones de cantidad determinada queda sujeta á la limitación del artículo 1650" (García Goyena, 1852, p. 114).

Se indica que este artículo está influido por una serie de otros códigos, entre los cuales se encuentran los artículos 1228 y 1229 el Código Civil francés y los artículos 2120 y 2121 del de Luisiana, por citar los más influyentes.

El insigne tratadista explica el sentido de esta norma, argumentando que el objeto de la cláusula penal es asegurar el cumplimiento de la obligación principal y no el de extinguirla y novarla. Por dicha razón, el acreedor debe quedar libre de escoger entre exigir el cumplimiento de la obligación principal por un lado, o bien el de la pena. Para poder sumar ambos, el cumplimiento forzado y la pena convencional, tendría que estar pactado expresamente.

El autor plantea que el perjuicio que genere el simple retardo, puede distinguirse como un perjuicio adicional y distinto del incumplimiento. Sin embargo, ya que la cláusula penal está establecida generalmente para asegurar el cumplimiento

\footnotetext{
${ }^{9}$ Art. 1079. "Hay obligación con cláusula penal, cuando el deudor se compromete á dar ó hacer alguna cosa para el caso de no cumplir la obligación".
} 
de la obligación principal y que aplicar una pena moratoria que se sume al cumplimiento de la obligación significa un cúmulo de penas, el autor entiende que para operar en dicho sentido, debe pactarse expresamente.

Por lo hasta aquí expuesto, vemos que la regla general es la prohibición del cúmulo de penas en el contexto de la aplicación de la cláusula penal, puesto que el objeto de ésta es asegurar el cumplimiento, ya sea por la vía forzada, o bien dando derecho al acreedor a optar por la indemnización convencional. El cúmulo, que podría ser una pena moratoria o bien una cláusula penal punitiva, no se presume, por lo que tiene que quedar expresamente establecida en dicho sentido para poder dar derecho al acreedor de exigirla de esa forma.

Lo anterior está en concordancia con lo explicado en cuanto a las obligaciones de cantidad determinada, caso en el cual "es imposible escapar a la tasas del artículo 1650, que (...) anulaba la pena puesta por razón de usura" (García Goyena, 1852, p. 115).

Debemos, por lo tanto, concluir que el antecedente que representa el proyecto de Federico García Goyena, seguido por nuestro legislador en esta materia, en concordancia con las explicaciones que entrega el autor en comento, que el cúmulo de penas en el ordenamiento jurídico chileno, en el contexto de las cláusulas penales, aparece históricamente cuestionado ,por regla general, en razón de la función de la cláusula penal, que es de asegurar el cumplimiento de la obligación principal por vías alternativas y en ningún caso, el de enriquecer al acreedor injustamente a costa del deudor moroso. Lo anterior encuentra su único límite en la voluntad de las partes, exigiendo la ley, sin embargo, que las partes lo estipulen expresamente en dicho sentido.

Otro punto importante a analizar a efectos de este artículo es el relativo a los antecedentes históricos acerca del requisito de la constitución en mora. El artículo 1082 del Código Civil español, en su proyecto de 1851, establece que:

"El cumplimiento de la cláusula penal solo puede exigirse en los casos y cuando concurran las circunstancias, en que, no existiendo la cláusula, se podrían reclamar los daños é intereses, según las reglas dadas en la Sección 3, capítulo 3 de este título" (García Goyena, 1852, p. 115).

El autor explica la redacción de este artículo con el anterior 1081, en razón de ser la pena convencional una compensación de daños e intereses, las normas que rigen la exigencia de la cláusula penal, son las generales sobre responsabilidad contractual, por lo que es necesario satisfacer el requisito de la constitución en mora del deudor para estos efectos.

Lo anterior se aplica para el caso de obligaciones positivas, ya que, como bien explica el citado autor, en caso de tratarse de una obligación de no hacer, la prueba 
Algunos aspectos de la cláusula penal en el derecho chileno.

de la falta se encuentra en la cosa hecha, por lo que su sola ocurrencia significa la mora del deudor (García Goyena, 1852, p. 116), en igual forma lo estableció el legislador chileno.

Admite sin embargo, aunque sin profundizar en la explicación, que el artículo 1230 del Código Civil francés es "más expresivo y concreto al caso de mora" (García Goyena, 1852, p. 115).

Debemos entender por tanto, que la constitución en mora del deudor, se exige siempre para el caso que quiera exigirse la pena convencional, al menos de acuerdo a las reglas generales sobre responsabilidad contractual.

\section{Tratamiento dispensado a la cláusula penal en el Código Civil chi- leno}

Según se analiza a continuación, y en el apartado siguiente, el Código Civil chileno, sigue al Código Civil francés, pero se aparta de éste en los siguientes aspectos:

a. Respecto a la definición de cláusula penal, el legislador chileno, establece que la pena se debe por la no ejecución o retardo en la obligación. El Código Civil francés ${ }^{10}$, en cambio sólo la contemplaba para el incumplimiento de la obligación principal al igual que el proyecto de Código Civil español de García Goyena.

b. En relación con la nulidad de la obligación principal que acarrea la nulidad de la cláusula penal, el Código Civil francés nada señala respecto a la estipulación en favor de otro. El Código Civil chileno, sigue al proyecto de Código Civil español, ya citado, indicando que la nulidad de la obligación principal no es aplicable a la estipulación en favor de otro ${ }^{11}$.

c. En relación con la reducción de la pena, el legislador chileno permite al sentenciador reducirla en caso que le parezca desproporcionada (Gatica Pacheco, 1959, pp. 307 y 308) ${ }^{12}$. En este sentido, Andrés Bello, sigue al Proyecto de Gar-

\footnotetext{
${ }^{10}$ El Código Civil francés sólo mencionaba la ejecución, aunque trataba los perjuicios moratorios, al referirse a las indemnizaciones.

11 "Pero valdrá la cláusula penal, á que se sujete un tercero, en los casos que vale la fianza por obligación nula ó que pueda ser anulada". García Goyena (1852, p. 113).

12 "229. Función del juez frente a la cláusula penal.- Las estipulaciones de la cláusula penal no sólo resultan obligatorias para las partes que la conciertan, sino también para el juez que conozca del litigio a que dé lugar el incumplimiento del contrato.

Sin embargo, el tribunal debe limitarse a declarar la procedencia o improcedencia de la pena que se reclama, sin que le sea lícito, de ordinario, alterar la suma prevista por las partes a título de pena, a menos que sea enorme o que el acreedor haya aceptado el cumplimiento parcial de la obligación principal, casos en los cuales puede ser disminuída en la forma prescrita por la ley.

La procedencia o improcedencia de la pena es siempre, por otra parte, materia de un juicio ordinario, ya que el establecimiento de sus requisitos es asunto de lato conocimiento. El cobro de la pena, en cambio,
} 
cía Goyena (1852), que dispone en el artículo 1085 "El juez puede modificar la pena estipulada cuando la obligación principal se hubiere cumplido en parte y no en el todo" (p.117) ${ }^{13}$.

En el derecho francés, el papel del juez se limita a la mera ejecución de lo pactado por las partes, sin embargo nuestro legislador, le otorga la facultad al juzgador de rebajar la pena, en caso de que le parezca enorme, estableciendo para el deudor un desequilibrio excesivo en la prestación, estableciendo algunas distinciones en relación a la naturaleza de la obligación, y estrictamente relacionada, con la obligación principal que cauciona (Vodanovic Haklicka, 1941, pp. 237 y 238). A mayor abundamiento, en relación al principio de prohibición de enriquecimiento injusto, cabe citar el artículo 1539 del Código Civil, que afirma que en caso de cumplimiento parcial de la obligación principal, aceptada por el acreedor, existe el derecho para el deudor de obtener una rebaja proporcional de la pena estipulada en garantía.

Lo anterior, por respeto a una de las reglas relativas al pago, la que éste debe ser íntegro - y por tanto de no poder obligar o compeler al acreedor a recibir pagos parciales- la aplicación de este artículo dependerá de la aceptación del pago fraccionado por parte del acreedor.

d. En relación a la opción del acreedor, para cobrar la indemnización o alternativamente la pena, sólo permite una u otra, a menos que haya existido estipulación en contrario.

En este sentido nuestro Código siguió el proyecto del Código Civil español (Corral Talciani, 2012, pp. 56 y 57) ${ }^{14}$, eliminando la referencia a la compensación de daños e intereses derivados del incumplimiento establecido en el artículo $1229^{15}$.

Cabe destacar, que el Proyecto sólo permitía la acumulación de la pena a la obligación principal, cuando aparezca que la pena fue pactada para indemnizar los perjuicios moratorios o el simple retardo.

puede perseguirse a través de un juicio ordinario o ejecutivo, según sea la naturaleza del título en que se funde".

${ }^{13}$ Cabe destacar que el Código Civil francés fue objeto de modificaciones en este sentido, permitiendo la moderación de la pena.

${ }^{14}$ Indica al respecto que "En el proyecto de 1853 se observa la idea de conectar la cláusula penal con la indemnización de perjuicios, pero ahora se sigue al proyecto de código civil español redactado por Florencio García Goyena, según lo apunta el mismo Bello en nota al art. 1721 de dicho proyecto. Se dispone así que "No habrá lugar a pedir el cumplimiento de la cláusula penal sino en los casos en que sin ella habría lugar a indemnización de perjuicios" (art. 1721).

Después del examen por la comisión revisora, se prevé la facultad del acreedor de demandar perjuicios si estos exceden a la pena, pero solo si así se le ha concedido expresamente. El proyecto inédito agregó un art. 1722 a, que dispone. "No podrá pedirse a la vez el cumplimiento de la cláusula penal y la indemnización de perjuicios, ni estará al arbitrio del acreedor preferir la indemnización a la pena; a menos de habérsele concedido expresamente la facultad de exigir ambas cosas, o cualquiera de ellas a su arbitrio".

Sólo en el último proyecto se modificará el criterio del Art. 1722, y se dirá que "Siempre estará al arbitrio del acreedor pedir la indemnización o la pena", véase Bello López (1890, pp. 390).

${ }^{15}$ Art. 1229 La cláusula penal es la compensación por los daños e intereses que el acreedor sufre por la inejecución de la obligación". 
Nuestro Código Civil sigue al legislador francés en disposiciones referidas a la nulidad de la obligación principal; la opción del acreedor de demandar la pena o el cumplimiento de la obligación principal; la necesidad de constituir en mora al deudor, entre otros aspectos.

\section{Régimen normativo y concepto de la cláusula penal}

La cláusula penal se encuentra regulada en el Código Civil chileno en el Libro IV "De las Obligaciones en general y de los Contratos" en el Título 110 "De las Obligaciones con Cláusula Penal", y su desarrollo corresponde a los artículos 1535 y siguientes (Gatica Pacheco, 1959, pp. 306 y 307$)^{16}$.

Indica el artículo 1535 que "La cláusula penal es aquella en que una persona, para asegurar el cumplimiento de una obligación, se sujeta a una pena, que consiste en dar o hacer algo en caso de no ejecutar o retardar la obligación principal".

Tal como se ha señalado, la cláusula penal es una especie de garantía, una caución pero para los efectos de su delimitación jurídica, no todos los autores se fijan en la exacta naturaleza de esta estipulación.

El tratadista Robert Pothier, fuente de consulta indiscutida del Código de Bello define la cláusula penal como "una convención en virtud de la cual una persona, para asegurar la ejecución de un primer compromiso, se obliga, en forma de pena, a alguna cosa en caso de inejecución de ese compromiso" (Pothier, 1947, p. 207).

Por su parte Alessandri Rodríguez (1939), omite referirse a su naturaleza específica apuntando a sus funciones como prestación sustitutiva de reforzamiento negocial. Así, la define como "La avaluación anticipada que las partes hacen en el contrato de los perjuicios que puede experimentar el acreedor con el incumplimiento de la obligación o con el cumplimiento imperfecto o tardío".

Reconoce, sin embargo, este autor que de lo dispuesto en el artículo 1535 Código Civil, se desprende que "su función es servir de garantía al cumplimiento de una obligación" (Alessandri Rodríguez, 1939, p. 104). En el mismo sentido se pronuncia el tratadista Vodanovic Haklicka (1941), quien afirma "Que la forma más sencilla de definir la cláusula penal es diciendo que es la avaluación hecha por las partes de los perjuicios que se originen por el no cumplimiento o por el cumplimiento tardío de la obligación" (p. 224). Pero al igual que Alessandri Rodríguez, reconoce la función de garantía, extraída de la definición del artículo 1535 Código Civil.

\footnotetext{
${ }^{16}$ Se refiere a la "ubicación de la cláusula penal" señalando que responde a las diversas funciones que cumple esta institución y que el legislador nacional recoge el criterio del Código Civil napoleónico. 
Por su parte Gatica Pacheco (1959, p. 317) plantea que una existe multiplicidad de funciones de la cláusula penal, las cuales no se contraponen entre sí 17 .

Desde una perspectiva más actual, Corral Talciani (2011), se refiere a esta estipulación adentrándose en sus funciones y presupuestos al señalar que la cláusula penal tiende a asegurar el cumplimiento de la obligación por la vía de la coacción mediante amenaza: las partes acuerdan que de no confirmarse lo previsto en un contrato principal, se siguen las consecuencias previstas en la cláusula penal.

La jurisprudencia ha reconocido que se trata de un pacto cuya función principal consiste precisamente la avaluación anticipada de los perjuicios. Señala que todas las funciones propenden a reforzar el cumplimiento del vínculo jurídico. Al respecto destaca que:

"Que (...) La doctrina por su parte, ha señalado que puede entenderse por tal "el pacto de una prestación a cargo del deudor y a favor del acreedor, representativa de la avaluación anticipada de los perjuicios y para el caso de incumplimiento en cualquiera de sus formas" ("Cumplimiento e Incumplimiento de las Obligaciones", Fernando Fueyo Laneri, Editorial Jurídica de Chile, 1991, pág. 467).

Este tipo de liquidación de perjuicios proviene directamente de las partes, ya que son ellas quienes pueden avaluar mejor que nadie los efectos del incumplimiento, inclusive considerando las razones particulares y hasta subjetivas que importan su real y verdadero interés en que las prestaciones se cumplan debidamente" (Corte Suprema, 24 de marzo de 2008, 136-2006, cons. 6).

\section{Naturaleza jurídica de la cláusula penal}

Pese a su denominación, la cláusula penal es una convención que genera obligaciones entre contratantes, siendo un contrato accesorio de aquellos definidos en el artículo 1442 del Código Civil chileno, puesto que su finalidad es asegurar el cumplimiento de una obligación principal y no puede subsistir sin ella, en el mismo sentido la definición de nuestro legislador al señalar que "La cláusula penal es aquella en que una persona, para asegurar el cumplimiento de una obligación, se sujeta a una

\footnotetext{
17 "La cláusula penal cumple, pues, simultáneamente, diversas funciones, todas ellas igualmente importantes y que, en conjunto, proporcionan a esta institución su evidente utilidad práctica. Debe rechazarse, en consecuencia, por artificiosa y falsa, la oposición que se señala entre unas y otras; o la primacía o exclusividad que se pretende respecto de algunas en desmedro de las demás, porque, como dice Ruggiero, haciendo una síntesis de todas ellas, la cláusula penal tiene conceptualmente siempre el mismo fin y una sola función, cual es la de reforzar el vínculo obligatorio, proporcionando al acreedor un medio más eficaz que la mera acción nacida del crédito simple que carece de esta estipulación accesoria. Esta mayor intensidad de su eficacia consiste precisamente en la amenaza que recae sobre el deudor, de agravar su responsabilidad ordinaria, si no cumple exacta y puntualmente la obligación, lo que permite estimular su diligencia"
}

Rev. derecho (Coquimbo, En línea) 2019, 26: e3893 
Algunos aspectos de la cláusula penal en el derecho chileno.

pena, que consiste en dar o hacer algo en caso de no ejecutar o de retardar la obligación principal"18.

Como objeto de la pena, deberán lógicamente quedar excluidas las obligaciones negativas o de no hacer, por la simple razón que la pena no podría consistir en una abstención, ya que sería un hecho atípico cuyo único sustento tendría que nacer de un acto consensuado por los contratantes.

Consecuencia de ser un contrato, como explica Somarriva Undurraga (1981, pp. 18 y ss.), es que la cláusula penal es una garantía personal, es decir, genera un crédito en favor del acreedor de la cláusula penal, para cobrar con determinada eficacia un derecho personal contra el deudor que se obliga en el contrato de cláusula penal.

Por otra parte, pueden disociarse las contrapartes en el contrato principal de las contrapartes y hasta los acreedores y deudores del contrato de cláusula penal. Por tanto, en su celebración, el contrato de cláusula penal debe distinguirse del contrato principal.

\section{Características del contrato de cláusula penal en Chile}

El contrato de cláusula penal en nuestro país es por naturaleza consensual, accesorio, condicional y tiene por finalidad la avaluación anticipada de los perjuicios. Describiremos aquellas características que conllevan consecuencias de interés:

\subsection{Accesorio}

Es consecuencia de su carácter de garantía, lo cual supone asegurar el cumplimiento de otra obligación que es la principal (Somarriva Undurraga, 1981, p. 18; Corral Talciani, 2012, pp. 111 y ss. ; Claro Solar, 1979, p. 505). A raíz del carácter de accesorio, es que este contrato sigue la suerte del contrato principal que garantiza. Así, si prescribe la acción para exigir judicialmente el contrato principal ${ }^{19}$, o bien si dicho contrato adolece de un vicio de nulidad ${ }^{20}$, estos efectos se extienden sobre la cláusula penal.

\footnotetext{
${ }^{18}$ Art. 1535 Código Civil.

${ }^{19}$ Por expresa remisión al artículo 2516 del Código Civil, que indica "La acción hipotecaria, y las demás que proceden de una obligación accesoria prescriben junto con la obligación a que acceden", en relación al artículo 1442 Código Civil, que indica "El contrato es principal cuando subsiste por sí mismo sin necesidad de otra convención y accesorio cuando tiene por objeto asegurar el cumplimiento de una obligación principal, de manera que no pueda subsistir sin ella".

${ }^{20}$ Nuestro legislador, se preocupó especialmente del tema, en el artículo 1536 del Código Civil, al señalar que "La nulidad de la obligación principal acarrea de la de clausula penal, pero la nulidad de ésta no acarrea la de la obligación principal".
} 
Consecuencia del mismo principio, es que los vicios o efectos que sufra el contrato accesorio, no se extienden sobre el principal.

Igualmente, la divisibilidad o indivisibilidad de la obligación principal, además de la cesión del crédito principal, arrastra igualmente al contrato de cláusula penal.

\subsection{Condicional}

La exigibilidad de la cláusula penal depende de un hecho futuro e incierto, consistente en el incumplimiento de la obligación principal. Como lo expresa el profesor Corral Talciani (2011, p. 485), la condición es suspensiva, expresa, potestativa y negativa.

Consecuencia de su carácter condicional y en virtud del artículo 1537 del Código Civil ${ }^{21}$, es que para exigirse válidamente, se requiere que el deudor sea constituido en mora (Somarriva Undurraga, 1981, p. 22).

\subsection{Constituye una avaluación anticipada y convencional de los perjui- cios}

El artículo 1542 del Código Civil, ordena prescindir de la existencia efectiva de perjuicios para exigir en todos los casos la pena convenida, mas no obsta a que la cláusula no pueda producir sus efectos en caso, por ejemplo, de un incumplimiento por caso fortuito o fuerza mayor, si así se estipula.

Es decir, la norma del artículo 1542 citado, opera al momento de analizar la necesidad de daños y perjuicios al momento de determinar la responsabilidad contractual del deudor, lo que debe siempre suponer un incumplimiento culpable de dicho deudor respecto de la obligación principal (Somarriva Undurraga, 1981, p. 22).

En este sentido Vodanovic Haklicka (1941) indica que este es justamente el espíritu del artículo 1542 del Código Civil, puesto que al tratarse de una avaluación convencional de los perjuicios, "No hay necesidad de probar los perjuicios"(p. 231).

Cabe agregar que según Somarriva Undurraga (1981, pp. 26 y 27) y dado el carácter accesorio de la cláusula penal, siempre deberá probarse la culpa del deudor en el incumplimiento de la obligación principal. En igual sentido se ha expresado Alessandri Rodríguez (1939, p. 107).

Nuestra Excelentísima Corte Suprema se pronunció acerca del alcance del art. 1542, pero se concentra, básicamente, en la función que cumple como estipulación

\footnotetext{
${ }^{21}$ Artículo 1537 Código Civil chileno, "Antes de constituirse el deudor en mora, no puede demandar a su arbitrio la obligación principal o la pena, sino sólo la obligación principal; ni constituido en mora el deudor en mora puede pedir a un tiempo el cumplimiento de la obligación principal y la pena...".

Rev. derecho (Coquimbo, En línea) 2019, 26: e3893
} 
que releva de la carga de la prueba del daño, pero sin extenderla a otros aspectos; al efecto señala:

"Ahora bien, en tanto avaluación convencional anticipada de los perjuicios, la cláusula penal, además de dejar en manos de los propios contratantes la determinación del monto de los perjuicios derivados del incumplimiento, libera al acreedor del peso de la prueba que, ordinariamente, debería rendir en orden acreditar el daño sufrido y su monto" (Corte Suprema, 14 de enero de 2010, 3393-2008).

En conclusión, el sentido y alcance del art. 1542 del Código Civil, es regular anticipada y convencionalmente el monto de los perjuicios que podrán cobrarse ante ciertos incumplimientos de las partes que celebran el contrato, su contenido no releva de probar los restantes requisitos de la responsabilidad contractual. A consecuencia de la avaluación anticipada, resulta de gran utilidad al eximir de la carga probatoria acerca del quantum de los perjuicios a la parte que la ejecuta. Asimismo, al haberse pactado, el hecho que al acreedor le produzca beneficios el incumplimiento o de contrario, no le produzca perjuicios, no obsta a su cumplimiento. Sin embargo, no libera el acreedor de acreditar el incumplimiento imputable además de la relación causal y la mora.

\section{Clasificación de las cláusulas penales}

Según las distinciones que propone Corral Talciani (2009), las cláusulas penales pueden clasificarse en tres categorías generales: compensatorias, moratorias y punitivas.

Dentro de las compensatorias pueden distinguirse, por un lado, las sustitutivas, que buscan una compensación por equivalencia, y por otro, las indemnizatorias, cuya finalidad es resarcir los perjuicios que causa el incumplimiento.

René Abeliuk, en cambio - de una forma más restrictiva- sólo las desglosa en cláusulas compensatorias y moratorias, señalando que "Puesto que la cláusula penal es una indemnización de perjuicios, puede ser compensatoria y moratoria; así lo confirma el Art. 1535, que habla de no ejecutar o retardar la obligación principal. La no ejecución es la que da lugar a la indemnización compensatoria, y el retardo, a la moratoria" (Abeliuk Manasevich, 1983, p. 573).

Agrega este autor, que no vale la pena referirse a su condición de sanción o pena, puesto que su función es garantizar el cumplimiento en equivalencia o naturaleza ${ }^{22}$.

\footnotetext{
${ }^{22}$ En el mismo sentido: "La cláusula penal, al igual que la indemnización judicial, y a diferencia de la legal, puede ser tanto compensatoria como moratoria; esto es, podrá venir a reemplazar el cumplimiento de la 
Entre éstas, la cláusula penal compensatoria es la regla general. Si es sustitutiva o indemnizatoria, es cuestión de interpretación del contrato.

Si la cláusula penal se ha pactado en función del simple retardo, entonces es moratoria. Para ser punitiva, los contratantes deberán estipularlo de modo expreso en el contrato de cláusula penal.

Como veremos más adelante, la clasificación es importante tanto desde el punto de vista de los derechos que podrá exigir el acreedor, como de los requisitos que tendrá que satisfacer para exigir su responsabilidad contractual.

\section{Ejecución de la cláusula penal}

Según se señaló precedentemente, la cláusula penal es un contrato que tiene por vocación acceder a un contrato principal, para garantizar al acreedor que recibirá el cumplimiento por parte de su deudor.

De constatarse el incumplimiento de la obligación principal, nace por tanto el derecho del acreedor para exigir lo acordado en el contrato penal. Como la cláusula penal es a su turno igualmente un contrato, responde por tanto a las normas de la responsabilidad contractual para hacerse exigible. Lo anterior, con ciertos matices y excepciones. Veremos cada uno de los requisitos de procedencia de la responsabilidad contractual, para ver cómo operan desde el punto de vista de la cláusula penal.

\section{1. El incumplimiento contractual}

La doctrina, de manera generalizada, concuerda que el incumplimiento consiste en el no pago de la prestación debida.

El objeto de la obligación puede incumplirse completamente, parcialmente o tardíamente. Cada una de estas categorías representa grados de cumplimiento de la obligación, que no satisfacen la regla del pago, que es la de pago íntegro de la misma y que impide al deudor obligar al acreedor a recibirlo escalonado o por partes.

Con esto, entendemos que en nuestro derecho, conforme a una buna parte de los autores que ocupan del tema y colacionamos en este trabajo ${ }^{23}$, reina el principio de la responsabilidad subjetiva, por ende, un daño o perjuicio le es imputable a un sujeto cuando es causado con dolo o culpa ${ }^{24}$.

obligación o tendrá lugar simplemente por el retardo en dicho cumplimiento". Vodanovic Haklicka (1941, p. 232)

${ }^{23}$ Ello, en aplicación del art. 1556 del Código Civil chileno, que indica "la indemnización de perjuicios comprende el daño emergente y el lucro cesante, ya provengan de no haber cumplido la obligación de haberse cumplido imperfectamente".

${ }^{24}$ En esta dirección nuestra Excelentísima Corte Suprema, ha señalado en diversos fallos que "para que proceda la indemnización de perjuicios es necesario que se encuentren acreditados los siguientes presu- 
Algunos aspectos de la cláusula penal en el derecho chileno.

Para el caso de la cláusula penal, el incumplimiento que interesa es el del contrato principal. El incumplimiento de la obligación principal equivale a incumplir (infringir) el contrato penal, dado su carácter de accesorio (Corral Talciani, 2012, pp. 116-119). De verificarse la inobservancia de la prestación principal debida, se cumple el primer requisito para exigir la pena contractual a la que accede ${ }^{25}$.

\subsection{Imputabilidad}

Para dar lugar a la reparación de daños y perjuicios por causa contractual, se requiere que el incumplimiento contractual sea inexcusable. Es decir, se requiere que el incumplimiento del deudor sea culpable. Fueyo Laneri (2004, pp. 421 y ss.) propone poner énfasis en que la responsabilidad contractual queda comprometida por el incumplimiento inexcusable, ya que la culpa en materia de responsabilidad contractual se presume.

Con esto, queda de cargo del incumplidor probar que su incumplimiento proviene de una causa que lo excusa, tal como son el caso fortuito y fuerza mayor. Según Fueyo Laneri (2004, pp. 397 y ss.), nuestro Código Civil toma a ambos por equivalentes. Para que haya lugar a alegar dichas causales que excluyen la culpa del deudor que incumple, deben satisfacerse los siguientes requisitos: debe ser una causa extraña al deudor; el hecho debe ser imprevisto; el hecho debe ser inevitable o irresistible.

Probado que por causa de fuerza mayor o caso fortuito no puede cumplirse con la obligación principal, la obligación accesoria seguirá por tanto la misma suerte, extinguiendo consecuencialmente esta obligación (Corral Talciani, 2012, pp. 179 y ss.).

Queda pendiente, si acaso más allá de la fuerza mayor o caso fortuito, el deudor alegará que el incumplimiento se produjo sin dolo ni culpa de su parte.

Al respecto, Corral Talciani (2012, pp. 180 y 181), afirma que nuestro Código no resuelve dicho caso y que la doctrina (Gatica Pacheco, 1959, pp. 410-415) ${ }^{26}$ pro-

puestos: a) Existencia de la relación jurídica de la cual se originan las obligaciones incumplidas; b) Existencia de obligaciones incumplidas o insatisfactoriamente ejecutadas; c) Existencia de daño o perjuicio procedente del incumplimiento de las obligaciones; d) Relación de causalidad entre el incumplimiento y el daño ocasionado; e) Existencia de un factor de imputación o culpa del deudor, que en materia de responsabilidad contractual se presume, una vez acreditado el incumplimiento; f) Que la obligación se encuentre vigente y no prescrita, como tampoco se acredite otro motivo que excuse o justifique el incumplimiento". Vid. por todos (Corte Suprema, 28 de enero de 2011, 5563-2009).

${ }^{25}$ Nuestra Excelentísima Corte Suprema ha indicado al respecto que; "En referencia a la imputabilidad del incumplimiento, debe ser voluntario e imputable, es decir, con dolo o culpa del deudor, no siendo procedente la resolución si ha mediado caso fortuito o fuerza mayor por cuanto, en tal caso, se habrá extinguido la obligación por otro modo de poner término a la misma como es la imposibilidad en el cumplimiento" (Corte Suprema, 30 de junio de 2011, 1738-2010).

${ }^{26}$ Establece los siguientes criterios en este punto: $1^{\circ}$ Incumplimiento por culpa del acreedor: no es responsable el deudor, por principio de equidad aceptado por la doctrina y carga probatoria es del deudor en este punto; $2^{\circ}$ Incumplimiento imputable a ambas partes: la pena debe ser disminuida en la medida que el acreedor haya influido en la inejecución de lo pactado; $3^{\circ}$ Incumplimiento por culpa o 
pone diversos resultados. Dentro de las diversas soluciones, estarían la posibilidad de exoneración del deudor si prueba su diligencia conforme al artículo 1547 del Código Civil. Otra opción que se postula es que la responsabilidad contractual es objetiva y que solamente el caso fortuito y la fuerza mayor liberan de responsabilidad al deudor.

Otros autores, identifican la falta de culpa con el caso fortuito, por la vía de conectar la obligación con el grado de diligencia impuesto al deudor. Finalmente, se propone distinguir entre el valor de la prestación y el valor de los perjuicios que se aparejan por su no cumplimiento y la falta de culpa, solamente liberaría al deudor de responder por lo segundo.

Sin perjuicio de lo anterior, el profesor Corral Talciani (2012, p. 184) concuerda en que se requiere que el incumplimiento le sea imputable al deudor. Es más, contempla la hipótesis en que el incumplimiento sea por hecho del acreedor. En este caso, deberá concluirse la inimputabilidad del deudor por la causal de culpa de la víctima o por la ruptura de la relación causal. Más aún -agrega- si la culpa fuere compartida entre el deudor y el acreedor, la pena debería disminuirse en proporción al grado de contribución del acreedor al incumplimiento, siguiendo la misma dirección que inspira el Art 2330 del Código de Bello ${ }^{27}$.

Con todo, por no estar expresamente regulado, Corral Talciani (2012, p. 184) admite que en esta materia deben regir las normas generales. Por lo tanto, corresponderá al deudor probar el caso fortuito o la fuerza mayor, como la ausencia de su culpa. Será, en consecuencia, el deudor penal quien deberá acreditar que el incumplimiento no le es imputable, para que en definitiva, proceda a liberarse de responsabilidad si acredita que actuó sin culpa ${ }^{28}$.

\subsection{Constitución en mora: requisitos y presupuestos}

\subsubsection{Concepto de mora}

Para que pueda exigirse la responsabilidad contractual del deudor, éste debe encontrarse constituido en mora de cumplir su obligación.

Fueyo Laneri citado por Ramos Pazosal (2004, p. 439), define a la mora como la "dilación injusta en el cumplimiento de una obligación". Es un retraso

dolo deudor: se presume su culpa si el acreedor prueba el incumplimiento (aplicación reglas generales sobre responsabilidad contractual).

${ }^{27}$ Art. 2330; del Código Civil "La apreciación del daño está sujeta a reducción, si el que lo ha sufrido se expuso a él imprudentemente."

${ }^{28}$ En el mismo sentido, "debe existir un nexo o relación inmediata, de causa a efecto, entre el acto o hecho del hombre (acción u omisión) y el evento o daño, de manera que se pueda inferir de ese nexo que el daño no se habría verificado sin aquel acto, en caso, debe ser pues premisa necesario para verificación del daño" (Ramos Pazos, 2004, p. 249).

Rev. derecho (Coquimbo, En línea) 2019, 26: e3893 
(Rodríguez Grez, 2003, pp. 201 y ss.) ${ }^{29}$ del cumplimiento motivado por la falta de su cooperación indispensable para el cumplimiento, o por su negativa a la aceptación de la prestación que se le ofrece (Rodríguez Grez, 2003, p. 441).

\subsubsection{Requisitos y necesidad de la mora}

Los requisitos de la mora, en relación con la exigibilidad de las cláusulas penales son los siguientes: Existencia de una obligación cierta, vencida y líquida; que exista retraso en el cumplimiento; que el retraso sea culpable, esto es, imputable a culpa o dolo del deudor; interpelación del acreedor al deudor, salvo los casos en que no se requiera esta conducta especial del acreedor, teniendo en consideración a que la mora parece necesaria para los casos de obligaciones positivas -dar o hacer- por no se concilia con las de no hacer.

La falta de alguno de estos requisitos, obsta a la debida constitución en mora del deudor y en consecuencia, a la exigibilidad de la responsabilidad contractual del deudor.

Analizados los dos primeros requisitos, es decir suponiendo su existencia, obligación exigible y retardo del deudor, corresponde analizar el requisito básico para constituir en mora, es decir la interpelación.

En esta dirección nuestra Excelentísima Corte Suprema ha señalado lo siguiente;

"SEXTO: Que, en lo que respecta a la mora del deudor (mora solvendi), es bien sabido que ésta consiste en el retardo imputable al deudor en el cumplimiento de su obligación, unido al requerimiento o interpelación del acreedor; de lo cual se pueden distinguir, desde el punto de vista cronológico, tres etapas o fases: la etapa de exigibilidad de la obligación, la etapa de retardo y, finalmente, la etapa de mora" (Corte Suprema, 11 de abril de 2011, 5494-2009).

En consecuencia, para los efectos de determinar el momento de la entrada en vigencia del estado de morosidad, resulta fundamental su constitución legal, esto es, demanda judicial y notificación válida de ésta. Sólo desde ese instante se producen los efectos de la mora y no tiene imperio para situaciones que acaecen en la etapa de exigibilidad de la obligación y del retardo, ya que, sería injusto sancionar en forma retroactiva, al deudor, afectando sus derechos, con anterioridad al inicio del término de la mora.

Esta retroactividad, no sólo sería arbitraria sino contraria a los principios que consagra nuestro Código Civil en esta materia, que no permite la discrecionalidad del

\footnotetext{
${ }^{29}$ Aun cuando no está reglamentada en nuestro medio cita varios ejemplos a partir de los cuales elabora una teoría y los principios que distinguen "mora" y "retardo".
} 
acreedor para los efectos de determinar desde cuándo entrará en vigor el estado de mora.

Por lo demás, esta conclusión se ve legalmente reforzada, ya que en forma explícita el art. 1537 del Código Civil $^{30}$, autoriza el cumplimiento de la obligación, incluso en la etapa preliminar de simple retardo y entiende que antes de constituido el deudor -legalmente en mora- el acreedor solo puede pedir el cumplimiento de la obligación principal, presumiendo que hasta ese momento no se le han provocado perjuicios.

\subsubsection{Interpelación válida del acreedor}

Se entiende en nuestro ordenamiento la "interpelación" como el acto por el cual el acreedor requiere al deudor para que cumpla la obligación no satisfecha oportunamente, que puede ser contractual o judicial. Antes de la intimación, se entiende que el retardo no perjudica al acreedor.

La interpelación contractual se produce por la mera llegada del plazo pactado por las partes, a menos que exista norma expresa en contrario. Tal es el primer caso que establece el artículo 1551 Código Civil, que entiende al deudor constituido en mora por la simple llegada del plazo a menos que exista norma en contrario.

Sin embargo, en lo que a cláusulas penales se refiere, el artículo 1538 dispone que "háyase o no estipulado un plazo" es decir, aun cuando las partes hayan pactado la interpelación contractual para constituir en mora al deudor por la sola llegada del plazo, en aplicación del artículo 1551, el acreedor para efectos de ejecutar la cláusula penal, debe necesariamente constituir en mora al deudor por la vía de la interpelación judicial.

Nos explican respecto a este especial requisito de requerimiento, que;

"Resulta pues que si el deudor no cumple la obligación dentro del término estipulado el deudor se constituye en mora y la pena es exigible, salvo que la ley, en casos especiales, exija que además se requiera al deudor para constituirle en mora. Cuando se exige el requerimiento del acreedor al deudor, no basta el transcurso del término para exigir la pena, la cual sólo podrá demandarse desde que es requerido el deudor" (Alessandri Rodríguez, Somarriva Undurraga, y Vodanovic Haklicka, 2004, p. 324).

Esta disposición no puede entenderse de otra forma y debe primar por el principio de especialidad, puesto que de lo contrario, vulneraría la congruencia del sistema chileno.

\footnotetext{
${ }^{30}$ Art. 1537 "Antes de constituirse el deudor en mora, no puede el acreedor demandar a su arbitrio la obligación principal o la pena, sino sólo la obligación principal".
}

Rev. derecho (Coquimbo, En línea) 2019, 26: e3893 
En definitiva, para efectos de ejecutar las clausulas penales no cabe la interpelación contractual, sino sólo la judicial y su justificación puede ser lo gravoso que resulta la pena para el deudor ye el efecto conminativo que presenta el requerimiento para el deudor.

Por su parte, y en sentido contrario, Gatica Pacheco (1959), opina que, la constitución en mora de la cláusula penal puede ser por: interpelación contractual (tácita o expresa) y reconvención judicial. Argumenta que se aplican las reglas de la mora en general y única norma que lo trata es el art. 1538 del Código Civil.

Interpreta que de la frase inicial del art. 1538 no se debe desprender que solo por reconvención judicial puede constituirse en mora al deudor, en efecto, expresa que: "tal explicación es errada y por entero innecesaria, ya que el art. 1538 del CC en parte alguna exige reconvención judicial, sino que sólo expresa la necesidad de constituir en mora al deudor para hacer exigible la pena, sin que sus disposiciones entrañen ninguna contradicción con lo expresado en el art. 1551 del mismo Código" (Gatica Pacheco, 1959, pp. 416 y 417). Por lo cual, concluye que la frase con que comienza el art. 1538 no es una modificación a las reglas generales de constitución de mora del deudor.

\subsubsection{Interpelación judicial}

Constituye la regla general, establecida en el $n^{\circ} 3$ del art. 1551, que señala "en los demás casos, cuando el deudor ha sido judicialmente reconvenido por el acreedor", es decir, en aquellas obligaciones donde no se haya establecido un plazo, o deba aplicarse una norma especial, (tal es el caso del art. 1538 Código Civil), se requerirá la interpelación judicial.

La doctrina señala que el término reconvención alude a la demanda judicial válidamente notificada (Alessandri Rodríguez, Somarriva Undurraga, y Vodanovic Haklicka, 2004, p. 300). En consecuencia la mora comienza desde la notificación judicial de la demanda, entendiendo como tal la que se presente como incumplimiento o resolución, sin dejar de lado las alternativas de medidas cautelares preliminares al litigio.

El citado profesor Corral Talciani (2012, p. 190), refiriéndose a las cláusulas penales moratorias, sostiene que debe también constituirse en mora de acuerdo a alguna de las fórmulas establecidas en el artículo 1551 del Código Civil. Especial relevancia tendrá la mora en la pena moratoria, pues si es periódica el juez deberá calcularla en la sentencia ${ }^{31}$.

\footnotetext{
${ }^{31}$ La Corte de Apelaciones de Santiago, en causa Rol No: 7389-1997 de 16 de abril de 2002, con el mismo razonamiento aclara, que antes del requerimiento, no hay mora, sólo retardo, explicando lo siguiente; "OCTAVO: Que por mora se entiende el retardo culpable en el cumplimiento de una obligación, unido al requerimiento de parte del acreedor. En derecho son cosas distintas e inconfundibles el retardo y la mora. La noción del retardo está estrechamente vinculada con la exigibilidad de una obligación. Lo que 
Abona la posición anterior lo dispuesto en el art. 1537, que indica "antes de constituirse en mora, no puede el acreedor demandar a su arbitrio la obligación principal o la pena" y el art. 1538 que indica "háyase estipulado un término o no dentro del cual debe cumplirse la obligación principal, el deudor no incurre en la pena sino cuando se ha constituido en mora", y lo ya señalado respecto del art. 1551, todos del Código Civil. En este mismo sentido, estuvo la Corte de Apelaciones de Rancagua, en causa Rol $N^{\circ}$ 1242-2007.

Nuestra Excelentísima Corte Suprema ha sostenido la posición mencionada, en diversos fallos, indicando al efecto lo siguiente ${ }^{32}$;

"Para que el acreedor cobre la pena, debe haber existido un incumplimiento imputable al deudor y mora de parte de éste. Al efecto el inciso primero del artículo 1538 del Código Civil prescribe: 'Háyase o no estipulado un término dentro del cual deba cumplirse la obligación principal, el deudor no incurre en la pena sino cuando se ha constituido en mora, si la obligación es positiva' (...)

De lo anterior se desprende que para estar en situación de mora se requiere, de conformidad con lo que prevé el artículo 1551 Nro. 3 del Código Civil, la intimación del acreedor al deudor para que efectúe la prestación vencida, requerimiento que las partes pueden convenir eliminar por estipulación previa, pactando que la mora se produce por el sólo retardo, a lo que se le ha llamado la 'interpelación contractual, la cual puede ser expresa (artículo 1551 Nro. 1 del Código Civil) o tácita (artículo 1551 Nro. 2 del Código Civil). Empero, hay casos en los cuales no basta el vencimiento del día cierto y determinado que las partes han estipulado a que se refiere el Nro. 1 del precepto indicado, constituyéndose por ende en una excepción a dicha norma; se exige por la ley, en cambio, una actividad especial del acreedor, una interpelación específica. En esta situación se coloca la ley tratándose particularmente de la cláusula penal, de acuerdo con lo prescrito en el artículo 1538 del mismo cuerpo normativo precedentemente transcrito". (Corte Suprema, 14 de enero de 2010, 3393-2008).

caracteriza principalmente a la mora es el requerimiento que hace el acreedor; mientras éste permanece inactivo, en silencio, no hay mora, sino retardo(...) DECIMO TERCERO: Que la institución de la mora siempre trae consigo el derecho de solicitar indemnización de perjuicios, lo cual el artículo 1.537 viene a confirmar al establecer que antes que el deudor se constituya en mora, sólo puede solicitarse el cumplimiento de la obligación, y una vez constituida, ésta o la indemnización; lo cual quiere decir, que apenas se constituye en mora nace el derecho del acreedor para solicitar indemnización de perjuicios y, la cláusula penal sólo es una forma especial de indemnización de perjuicios, que se pacta en las obligaciones de dar(...) DECIMO QUINTO: Que, en consecuencia, para exigir la cláusula penal deben reunirse los mismos requisitos que para poder solicitar la indemnización de perjuicios (...)".

${ }^{32}$ En el mismo sentido, Rol N5145-2006, de 8 de Abril de 2008 y Rol N²036-2010.

Rev. derecho (Coquimbo, En línea) 2019, 26: e3893 
Por otro lado la Corte de Apelaciones de Santiago, confirmó el razonamiento que se ha venido sosteniendo, esto es, el requisito de la notificación válida de la demanda ${ }^{33}$, aclarando que no sólo es necesaria la interposición de la demanda sino que también la notificación conforme a la ley.

Existe -por último- un argumento histórico, don Andrés Bello, al modificar la disposición, revisó todas las disposiciones de proyectos anteriores, referidos al actual art. 1551, y en todas ellas se establece este requisito de la misma manera, partiendo del Proyecto de 1842, de la comisión bicameral ${ }^{34}$. Especial relevancia tiene el proyecto de Código Civil de 1853, que en su artículo 1730, cuya redacción es la más similar a la actual disposición indicaba lo siguiente:

$" 1{ }^{\circ}$ Cuando no ha cumplido la obligación dentro del término estipulado si en el contrato se expresa que por la mera expiración del término queda constituido en mora, salvo que la ley en casos especiales requiera la reconvención judicial no obstante cualquier expresión del contrato" (Bello López, 1995, p. 472).

Lo cual relacionado con el art. 1538 del Código Civil, conlleva a una aplicación lógica y armoniosa de la expresión "háyase estipulado un término o no..." que utiliza la referida disposición. Es absolutamente concluyente en este supuesto que en materia de cláusulas penales aun cuando se haya acordado un término o plazo en el contrato para la ejecución de la pena, requiere el acreedor interpelar judicialmente al deudor. En tal caso, a nuestro juicio, dicha exigencia es de orden público y por lo tanto, no disponible por las partes.

\subsubsection{Concurrencia de incumplimiento recíproco: excepción de contrato no cumplido o purga de la mora}

Hasta aquí, se trata de la mora de una de las dos partes del contrato. Sin perjuicio de lo anterior, la mora puede darse simultánea y recíprocamente, es decir, que cada una de las partes, deudor y acreedor, se encuentren atrasadas en el cumpli-

\footnotetext{
${ }^{33}$ Algunos han sostenido como equivalente que la solicitud de constitución de un arbitraje, operaría con el carácter de "reconvención judicial", conforme a los términos del numeral tercero del art. 1551 del Código Civil. Ello claramente constituye una inexactitud que no se ajusta al derecho vigente, ya que la Interpelación en todo caso, debe hacerse por la vía judicial, a través de una demanda - sea en sede ordinaria u arbitral y legalmente notificada. Prueba de ello, es el art. 2510 del Código Civil, en materia de interrupción de la prescripción, que exige en el numeral primero, que la notificación de la demanda se haga en forma legal.

Este requisito, por lo demás, es la regla general en materia civil, laboral, tributaria y comercial.

No obsta a la conclusión anterior lo dispuesto en el art. 1672, puesto que esta disposición se refiere a una excepción a la extinción de la obligación cuando la cosa perece o desaparece, por culpa o constituido legalmente en mora el deudor, haciendo presente que esta norma corresponde al título XIX del Libro Cuarto, "De la perdida de la cosa que se debe".

${ }^{34} \mathrm{El}$ proyecto de 1842 indicaba; "Lo anterior se entiende sin perjuicio de leyes especiales que induzcan la mora por la simple expiración del término o que requieran la interpelación judicial no obstante cualquier expresión del contrato".
} 
miento de sus obligaciones en un contrato. Si dicha situación se presenta en un contrato bilateral, dado el principio de interdependencia y reciprocidad de las prestaciones, el profesor Fueyo Laneri (2004) entiende que la extensión de los efectos del contrato penal se prolonga, conforme al tenor del artículo 1552 del Código Civil a cada una de las partes. Por lo tanto, resulta oponible la excepción de contrato no cumplido hasta que la parte incumplidora, cumpla o bien se encuentre llana a cumplir por su parte.

La solución que sugiere Fueyo Laneri (2004), debe extenderse a la que, a su turno postula Corral Talciani, en cuanto a que en el contexto del contrato penal, se aplican las mismas normas sobre responsabilidad contractual que al contrato principal al que accede (Bello López, 1995, pp. 470 y ss.). En efecto, lo afirma expresamente, asegurando que "la doctrina está conteste en que esta regla -la de excepción de contrato no cumplido- se aplica también a la cláusula penal, por lo que no podrá reclamarse la pena estipulada para garantizar una obligación emanada de un contrato bilateral si el acreedor de ésta no ha cumplido o no se allana a cumplir su propia obligación recíproca" (Corral Talciani , 2012, p.191).

\subsubsection{Caso de inimputabilidad del deudor}

Puede ocurrir que el retardo se deba también a otras circunstancias no imputables al deudor, tales como el caso fortuito o fuerza mayor, caso en el cual el deudor no está en mora o cuando exista ausencia de culpa.

En este punto conviene aclarar el sentido y alcance del artículo 1542 del Código Civil, respecto a si al exonerar de la prueba del daño al acreedor, obliga también al deudor a responder igualmente del caso fortuito o fuerza mayor.

En este sentido, Corral Talciani explica que en ese caso la cláusula penal se transformaría en otra figura, descartando coherencia en el sistema interno, transformando el régimen de responsabilidad, de subjetiva a objetiva.

Aclara -igualmente- que dicho pacto se encuentra permitido por aplicación del artículo 1547 inc. $4^{\circ}$ del Código Civil que dispone que las partes pueden alterar las normas de la responsabilidad por medio del ejercicio de la autonomía contractual.

Sin perjuicio de lo anterior, entendemos que dicho pacto debe constar de manera expresa y además, creemos que la dispensa de la prueba del daño, mas no del requisito de la imputabilidad al deudor quien puede alegar a su favor, caso fortuito o fuerza mayor.

Respecto al caso fortuito nos indica que;

"En cuanto al artículo 1558, según el cual la mora producida por fuerza mayor o caso fortuito no da lugar a la indemnización de perjuicios, cabe obser- 
var en realidad que la mora generada por fuerza mayor o caso fortuito no es mora, sino simplemente retardo, y que aquella supone siempre culpa o dolo del deudor. El legislador debió decir entonces, que el retardo -no la moraproducido por fuerza mayor o caso fortuito no da lugar a indemnización de perjuicios ya que no constituye mora en su sentido específico. Por tanto debe concluirse que la palabra mora empleada en el artículo 1558 lo ha sido con el significado de retardo" (Alessandri Rodríguez, Somarriva Undurraga, y Vodanovic Haklicka, 2004, p. 292).

Esto está en concordancia con el artículo 1538 del Código Civil. Para que exista la mora, es necesaria por tanto la interpelación del deudor. Del solo incumplimiento, solamente puede constatarse que hay retardo en el cumplimiento de la obligación, mas no hay constitución en mora.

\subsubsection{Exigibilidad de la obligación}

Asimismo, la exigibilidad de la obligación no implica necesariamente la mora. Según los autores recientemente citados, la disposición del Art. 1551 del Código Civil, podría inducir a pensar que la exigibilidad de la obligación y la mora son la misma cosa. Sin embargo, si en apariencia coinciden, la disposición continúa señalando: "salvo que la ley en casos especiales exija que se requiera al deudor para constituirle en mora". Analizado lo anterior en relación al artículo 1538 del mismo cuerpo legal, podemos concluir que en el caso de las cláusulas penales siempre se requiere la constitución en mora, vía interpelación judicial, por tratarse de una cláusula especial y en razón de estar frente a una norma imperativa.

Esto vale aun cuando se haya estipulado un término para el cumplimiento de la obligación, siendo aplicable dicha disposición tanto para las cláusulas penales moratorias como compensatorias.

Esta conclusión se ve reafirmada por el artículo 1557 que establece la regla general respecto de la obligación de indemnizar perjuicios, abonando la conclusión respecto a las cláusulas penales ${ }^{35}$.

Con todo, debe concluirse que el requisito de constitución en mora opera plenamente en el contexto del contrato penal, lo que incluye la excepción de contrato no cumplido. Se excluye sin embargo, el estado de mora en aquellos contratos bilaterales en que ambas partes, no han cumplido o no se encuentran al menos llanas a cumplir.

\footnotetext{
${ }^{35}$ Art. 1538 Código Civil chileno "Háyase o no estipulado un término dentro del cual deba cumplirse la obligación principal, el deudor no incurre en la pena sino cuando se ha constituido en mora, si la obligación es positiva".

Art. 1557 Código Civil chileno "se debe la indemnización de perjuicios desde que el deudor se ha constituido en mora, si la obligación es de no hacer desde la contravención".
} 


\subsection{Daño}

Por tener un fin eminentemente reparatorio y por el principio de justicia correctiva que lo informa, el daño es requisito esencial de la responsabilidad civil.

Sin embargo, en el contexto de la cláusula penal, el requisito del daño, se encuentra previsto por el propio contrato penal, tanto en su existencia como por su monto, por lo que por disposición expresa, se impide la discusión de su existencia o su monto con ocasión de un incumplimiento (Fueyo Laneri, 2004, pp. 486 y ss. ; Corral Talciani , 2012, pp. 196 y 197), pena que de acuerdo al Art 1544 puede ser inferior -en cantidad- al daño efectivo. Empero, nunca podrá ser superior al duplo de la misma ya que se genera el derecho correlativo a la rebaja proporcional.

Por tanto, el único requisito distinto respecto de la responsabilidad contractual común, dice relación con la necesidad de que el acreedor deba probar los perjuicios. En efecto, queda liberado de la prueba de los perjuicios, en atención a lo dispuesto en el art. 1542 del Código Civil.

Abeliuk Manasevich (1983) indica, que "en consecuencia no hay necesidad alguna de distinguir entre daño emergente y lucro cesante, daños directos o indirectos, previstos o imprevistos, morales o materiales" (p. 578).

Vodanovic Haklicka (1941), abona la opinión anterior, indicando que "de acuerdo con el art. 1542, hay derecho a cobrar la pena por el sólo hecho de infringirse la obligación y el deudor no será admitido a probar que la infracción no ha causado perjuicio al acreedor o le ha producido beneficio" (p. 225).

En síntesis, por lo hasta aquí expuesto y para efectos de ejecutar una cláusula penal, el acreedor deberá:

1. Acreditar incumplimiento imputable al deudor (considerando la presunción de culpabilidad en la responsabilidad contractual);

2. Constituir en mora al deudor, para lo cual deberá requerirlo en forma judicial, es decir presentar y notificar válidamente la demanda. Siendo ésta la regla general en materia de cláusulas penales.

3. No deberá acreditar los perjuicios puesto que fueron avaluados anticipadamente.

\subsection{Causalidad}

Por su parte, el artículo 1556 del Código Civil señala que los daños deben provenir del incumplimiento de la obligación y el artículo 1558 de dicho cuerpo normativo los limita a aquellos que fueron consecuencia directa o inmediata del incumplimiento (Abeliuk Manasevich, 1983, pp. 522-523; Corral Talciani, 2008, p. 129 y ss.). Este es el requisito de relación de causalidad entre el incumplimiento y el daño que 
debe existir para determinar que la existencia del daño proviene efectivamente del incumplimiento del deudor y para determinar un límite a la extensión de responsabilidad, el cual es excluir la obligación de reparar daños indirectos, por cuanto falta la relación de causalidad entre el incumplimiento y el daño.

Se debe hacer notar que lo anterior es sin perjuicio de lo que sostiene la doctrina encabezada por Peñailillo Arévalo (2009, pp. 331 y ss.) y seguida por Carlos Pizarro Wilson (2013) ${ }^{36}$ acerca de la responsabilidad contractual a propósito de las obligaciones de resultado concernientes a obligaciones derivadas de las prestaciones médicas. En tal supuesto, la culpa o grado de diligencia exigible deja a un lado el factor de atribución establecido en el artículo 1547 del Código Civil y pasa a desprenderse derechamente de la noción de responsabilidad objetiva que deriva específicamente del incumplimiento o la obtención de un resultado concreto, tal como lo plantea el artículo 1556 del mimo cuerpo legal.

En este caso, podría aparecer como discutible la obligación de acreditar la vinculación causal que releva por tanto de la existencia y la prueba del daño.

En esta hipótesis bastaría, el incumplimiento.

Volviendo, sin embargo a la regla general, en palabras del profesor Corral Talciani (2008, p. 130), la causa del daño en el contrato es típico: el daño que funda la responsabilidad contractual, debe provenir de una causa, que es el incumplimiento del contrato.

La distinción de la categoría de la causalidad en la responsabilidad contractual- vinculando incumplimiento con daño- es relevante, por cuanto de la sola constatación del incumplimiento no presupone necesariamente el de la causalidad ni la producción de perjuicios para el acreedor (Corral Talciani, 2008, p. 131; Gatica Pacheco, 1959, pp. 422-424) ${ }^{37}$.

En efecto, según Corral Talciani (2008, pp. 137 y ss.), puede disociarse el incumplimiento de la autoría del deudor y de la producción de daños. Para nuestros efectos, en la producción del incumplimiento, debe atenderse a quienes estaban sujetos a observar la obligación y por causa de qué agente intervino el incumplimiento. Así, este autor, distingue los casos en que existan codeudores sujetos al cumplimiento de una misma obligación o al hecho de un tercero del que el deudor no responda, como causantes del incumplimiento que significan un quiebre de la causalidad entre el hecho del deudor, el incumplimiento y la producción del daño.

\footnotetext{
${ }^{36}$ Documentos gentilmente facilitado por su autor.

${ }^{37} \mathrm{Al}$ tratar los elementos necesarios para configurar la responsabilidad contractual en la cláusula penal no trata la causalidad. Al parecer esto se debe, a cómo desarrolla elemento "daño" planteando que existe una equivalencia presunta entre el monto real de la pena y el perjuicio experimentado. Tal presunción, de derecho, da por establecida la existencia del daño y su cuantía, por lo cual no se puede modificar la pena, aun cuando en los hechos no exista equivalencia.
} 
Con ello, el autor propone estudiar los casos en que existe pluralidad de deudores y la concurrencia del hecho de un tercero por el que el deudor no responde.

Para el caso en que una obligación deba cumplirse por acto de varios deudores, debe distinguirse. Si uno solo de ellos determina el incumplimiento, éste será el único responsable de reparar perjuicios. Si el caso fuere que los deudores "se comprometen a realizar acciones independientes, pero en colaboración para obtener la prestación [y] rehúsan, ninguno puede eludir su responsabilidad aduciendo que la prestación hubiera permanecido incumplida de todos modos por la falta de cumplimiento del otro" (Corral Talciani, 2008, p. 138). Si solamente uno de los deudores fuera renuente a cumplir, se propone la solución de hacer responsable a ese solo deudor, por efecto del artículo 1534 del Código Civil. ${ }^{38}$

Si bien debe existir un nexo de causalidad entre incumplimiento y daño para hacer efectiva la obligación de indemnización por responsabilidad contractual, en el contexto del contrato penal, -según se indicó- nos encontramos con los perjuicios avaluados anticipada y convencionalmente, es decir, para efectos de determinar la cuantía del daño, no se atenderá tampoco al nexo causal señalado.

Ramos Pazos, indica que los perjuicios que se indemnizan son los que provienen del incumplimiento. Cita a Messineo quien expresa esta idea señalando que "debe existir un nexo o relación inmediata, de causa a efecto, entre el acto o hecho del hombre (acción u omisión) y el evento o daño, de manera que se pueda inferir de ese nexo que el daño no se habría verificado sin aquel acto, debe ser pues premisa necesario para verificación del daño" (Ramos Pazos, 2004, p. 249).

Alessandri Rodríguez (1939, p. 112), en relación a la dispuesto en el art. 1542 del Código Civil, indica que se ha intentado sostener que el deudor debe responder de la pena en todos los casos, incluso cuando el incumplimiento no le es imputable, dado que el precepto utiliza la expresión "en todos los casos" sin embargo, sostiene

\footnotetext{
${ }^{38}$ En el mismo sentido, Díez Picazo (2008, p. 736 y 737) "La imposibilidad sobrevenida de la prestación, determinante de un incumplimiento definitivo y de una definitiva insatisfacción del derecho de crédito, puede obedecer a comportamientos imputables al acreedor. [Tal es el caso] en que el acreedor hace imposible el facere o el servicio comprometido por el deudor (...) En todos estos casos, la imputación de los hechos determinantes del impedimento de prestación al acreedor excluye, en todo caso, la responsabilidad del deudor por los daños y perjuicios. Si además, nos encontramos en presencia de una imposibilidad sobrevenida de carácter objetivo y absoluto, se habrá producido la liberación de que habla el art. 1182. Si la obligación de la que el deudor queda liberado se encontraba inserta en una relación obligatoria de carácter sinalagmático, debe entenderse que el deudor liberado conserva su derecho a la contraprestación o remuneración que en virtud del contrato debía recibir". Agrega que "La imputación al acreedor de su propia insatisfacción puede ser consecuencia de la falta de observancia por él de su carga de cooperar o colaborar con el deudor a fin de que éste se encuentre en las necesarias condiciones para llevar a cabo la prestación prometida, lo que es especialmente importante en todos aquellos casos en que el deudor no se encuentra en condiciones de llevar a cabo por sí solo la ejecución de la prestación prometida". (p. 737).
} 
que se trata de una disposición que apunta a la prueba del daño, no pudiendo excusarse el deudor del pago de la pena a pretexto de que el incumplimiento no produce perjuicio al acreedor, aclarando que el caso fortuito o fuerza mayor exonera de toda responsabilidad al deudor, aún del cumplimiento mismo de la obligación, cuando lo ha hecho imposible. Con todo, vale concluir que la relación causal será importante en el contrato penal, solamente para verificar que el incumplimiento del deudor fue el que generó el daño. Comprobado lo anterior, la extensión de la reparación estará determinada por la propia cláusula penal, sin importar los demás elementos que se aplican generalmente en la evaluación de los perjuicios en responsabilidad contractual, salvo que el acreedor renuncie a la aplicación del contrato penal, para preferir la aplicación de las normas generales sobre responsabilidad contractual.

\section{Conclusiones}

En lo relacionado con las cláusulas penales, el legislador chileno, reconoce fuertemente la influencia del Código Civil francés, pero se aparta de éste en aspectos específicos, siguiendo al proyecto de Código Civil español, redactado por García Goyena. Nuestro legislador, mantuvo la naturaleza jurídica de contrato-caución y sus características principales, se trata de un contrato accesorio, condicional y constituye la avaluación anticipada de los perjuicios.

La naturaleza jurídica de la cláusula penal es la de ser un contrato. Como tal, se somete a las normas generales sobre responsabilidad contractual al momento de verificarse el incumplimiento de parte del deudor.

En consecuencia, la sola verificación de un incumplimiento no es suficiente para hacer valer la cláusula penal. En particular, el incumplimiento debe ser culpable, por lo que debe satisfacerse la exigencia de imputabilidad del deudor que incumple. Para su ejecución y siendo fiel a sus antecedentes históricos, requiere la constitución en mora del deudor por la vía judicial, el incumplimiento imputable al deudor y acreditar la existencia de la obligación, sumado a una relación de causalidad entre el incumplimiento y los perjuicios. Además se requiere que el acreedor no se encuentre a su vez en mora de cumplir si el contrato es bilateral.

Con todo, si bien no es necesario probar la existencia ni el monto del daño, sí será necesario que el daño haya tenido lugar a causa del incumplimiento del deudor contra quien se persigue la responsabilidad.

No se exige al acreedor la acreditación del quantum de los perjuicios. En relación a la causalidad, su estudio se limitará a poner en relación al deudor con el incumplimiento dañoso, mas no versará sobre la extensión de los daños a reparar, puesto que los perjuicios se encuentran previa y de común acuerdo determinados en el contrato penal, según lo dispone el art. 1542 del Código Civil, antes mencionado. 
En definitiva y a modo de conclusión, para efectos de ejecutar una cláusula penal, el acreedor deberá acreditar:

1. Incumplimiento imputable al deudor (la culpa se presume).

2. Mora del deudor.

3. Deberá acreditar que existe una relación de causalidad entre el incumplimiento y el daño.

4. No deberá acreditar los perjuicios puesto que fueron avaluados anticipadamente.

5. En nuestro ordenamiento jurídico se encuentra vedado, salvo pacto expreso, la acumulación de la obligación principal y la pena compensatoria.

6. Respecto a la pena moratoria, al igual que el Código Civil francés, se permite su acumulación a la obligación principal, si aparece que se ha pactado por el simple retardo.

7. No podría acumularse la pena moratoria y compensatoria, a menos que las partes lo hayan pactado expresamente.

8. Por último, no pueden ejecutarse las penas, si es que el acreedor opta por la resolución del contrato a menos que se haya estipulado expresamente.

\section{Referencias Bibliográficas}

Abeliuk Manasevich R. (1983). Las obligaciones (2a ed., Vol. 2). Santiago: Ediar.

Alessandri Rodríguez, A. (1939). Teoría de las obligaciones. Santiago: Zamorano y Caperán.

Alessandri Rodríguez, A., Somarriva Undurraga, M. y Vodanovic Haklicka, A. (2004), Tratado de las Obligaciones (2a ed.). Santiago: Editorial jurídica de Chile.

Banco Citibank S.A. con Cruz Pavez Roberto y otro, 5494-2009 (Corte Suprema 11 de abril de 2011). Recuperado de https://bit.ly/355DFY4

Bello López, A. (1995) Código civil de la República de Chile. Caracas: Ediciones del Ministerio de Educación.

Bello López, A. (1890). Proyecto Inédito del Código civil (Vol. 13). Santiago: Imprenta Pedro G. Ramírez. Recuperado de https://bit.ly/2s4lsLZ

Chile, Ministerio de Justicia. (2015). Código civil. Recuperado de http://bcn.cl/1uu74

Claro Solar, L. (1979). Explicaciones de derecho civil chileno y comparado (Vol. 10). Santiago: Editorial jurídica de Chile. 
Algunos aspectos de la cláusula penal en el derecho chileno.

Corral Talciani, H. (2008). Causalidad y previsibilidad en la responsabilidad contractual. Cuadernos de extensión jurídica, (15), 115-179. Recuperado de https://bit.ly/36eqmEZ

Corral Talciani, H. (2009). La cláusula penal en la resolución del contrato. En E. Alcalde Rodríguez y H. Fábrega Vega (Coords.). Estudios jurídicos en homenaje a Pablo Rodríguez Grez, Santiago: Ediciones Universidad del Desarrollo.

Corral Talciani, H. (2011). La cláusula penal y convenciones modificatorias de la responsabilidad. En A. Zúñiga Tejos (Ed.). Estudios de derecho privado: en homenaje al jurista René Abeliuk Manasevich. Santiago: Editorial jurídica de Chile.

Corral Talciani, H. (2012). La cláusula penal. Santiago: Editorial jurídica de Chile.

Cubillos Orrego Andres con Figueroa Del Rio Raul German y otros, 136-2006 (Corte Suprema 24 de marzo de 2008). Recuperado de https://bit.ly/2PuqkC2

Díez Picazo, L. (2008). Fundamentos del derecho civil patrimonial (6a ed. Vol. 2). Pamplona: Civitas.

España (1889). Código Civil. Recuperado de https://bit.ly/2s8QdPM

France (1804). Code Civil. Recuperado de https://bit.ly/2PrIWnj

Fueyo Laneri, F. (2004). Cumplimiento e incumplimiento de las obligaciones (3a ed.). Santiago: Editorial jurídica de Chile.

Gatica Pacheco, S. (1959). Aspectos de la indemnización de perjuicios por incumplimiento del contrato (Del incumplimiento de las obligaciones contractuales; de los perjuicios y de su liquidación judicial, legal y convencional. De la cláusula penal. Artículos 1.556, 1.558, 1.559 y 1.535 a 1.544 del Código Civil) Santiago: Editorial jurídica de Chile, 1959.

García Goyena, F. (1852). Concordancias, motivos y comentarios del Código Civil español (Vol. 3). Madrid: Imprenta de la Sociedad Tipográfico-Editorial. Recuperado de https://bit.ly/2PoXyD2

Larroumet, C. (1999).Teoría general del contrato (J. Guerrero R., Trad.) (Vol. 2). Santa Fe de Bogotá, Temis.

Lopez Gonzalez Alex Alberto con Albarracin Cordova Patricio Antonio, 1738-2010 (Corte Suprema 30 junio de 2011). Recuperado de https://bit.ly/36geKkY

Mazeaud, H., Mazeaud, L y Tunc. A. (1977) Tratado teórico y práctico de la responsabilidad civil delictual y contractual (L. Alcalá-Zamora y Castillo. Trad.) (Vol. 3). Buenos Aires: Ediciones jurídicas Europa-América. 
Peñailillo Arévalo D. (2009). Responsabilidad contractual objetiva. En C. Pizarro Wilson (Coord.). Estudios de derecho civil (Vol. 4, pp. 331-346). Santiago: Legal Publishing.

Pinto Zañartu Ximena Maria del Carmen /Galeria Epoca S.A., 7389-1997 (Corte de Apelaciones de Santiago 16 de abril de 2002). Recuperado de https://bit.ly/2Ppf3D9

Pizarro Wilson, C. (2013). La Obligación de resultados en el contrato médico. Hacia una responsabilidad objetiva. Fondecyt Regular $\mathrm{N}^{\circ}$ 1130171. Recuperado de https://bit.ly/2P3up1k

Poli Cerraduras Limitada con Inmobiliaria Iberoamericana S, A., Universidad Iberoamericana, 3393-2008 (Corte Suprema 14 de enero de 2010). Recuperado de https://bit.ly/34481ca

Pothier, R. (1947). Tratado de las obligaciones. Buenos Aires: Atalaya.

Ramos Pazos, R. (2004). De las obligaciones. Santiago: Lexis Nexis.

Rodríguez Grez, P. (2003). Responsabilidad contractual. Santiago; Editorial jurídica de Chile.

Somarriva Undurraga, M. (1981). Tratado de las cauciones. Santiago, Contable Chilena Ltda.

Soc. Comercial Quilvo Alto Ltda. con Soc. Petreos S. A, 5563-2009 (Corte Suprema 28 de enero de 2011). Recuperado de https://bit.ly/38j1eyH

S.P. Inversiones e Informatica Limitada con Inversiones Valle Alegre Limitada, 5145-2006 (Corte Suprema 8 de abril de 2008). Recuperado de https://bit.ly/2s99bpu

Vidal Danks Rodrigo Ernesto, Gutierrez Ramos Gaston Renato con Daroch Merino Patricio Sergio Emilio, Fischer Eastman Jerman, 2036-2010 (Corte Suprema 8 de septiembre de 2011). Recuperado de https://bit.ly/2sb3rvm

Vodanovic Haklicka, A. (1941). Curso de derecho civil. Basado en las explicaciones de don Arturo Alessandri Rodríguez y Manuel Somarriva Undurraga (Vol. 3). Santiago: Nascimiento.

\section{Para citar este artículo bajo Norma APA 6a ed.}

Prado Puga, A. (2019). Algunos aspectos de la cláusula penal en el derecho chileno. Revista de Derecho (Coquimbo.

En línea), 26, e3893, https://doi.org/10.22199/issn.07189753-2019-0016 